\title{
THE INFLUENCE OF BRAND ORIENTATION AND KNOWLEDGE CREATION ON ORGANISATIONAL PERFORMANCE OF MALAYSIAN TOURIST RESORTS
}

\author{
Melissa Li Sa Liow ${ }^{1,3 *}$, Kim Chai Yeow ${ }^{2}$, Choon-Yin Sam ${ }^{3}$, and John Aik Joo Heng ${ }^{3}$ \\ ${ }^{1}$ International University Malaya-Wales, Block A, Administration Wing, City Campus, \\ Jalan Tun Ismail, 50480 Kuala Lumpur, Malaysia \\ ${ }^{2}$ Faculty of Computer Science and Information Technology, University of Malaya, \\ Jalan Universiti, 50603, Kuala Lumpur, Malaysia \\ ${ }^{3}$ PSB Academy Singapore, 6 Raffles Boulevard, \#03-200, Singapore 039594 \\ *Corresponding author: melissa.liow@psb-academy.edu.sg
}

Published online: 27 June 2019

To cite this article: Liow, M.L.S., Yeow K.C., Sam, C.-Y., and Heng, J.A.J. (2019). The influence of brand orientation and knowledge creation on organisational performance of Malaysian tourist resorts. Asian Academy of Management Journal, 24(1), 175-204. https://doi.org/10.21315/aamj2019.24.1.8

To link to this article: https://doi.org/10.21315/aamj2019.24.1.8

\begin{abstract}
The purpose of this paper is to examine the effects of brand orientation and knowledge creation process on the organisational performance of tourist resorts from the perspective of tourism entrepreneurs. Despite a plethora of branding and knowledge management literature, a limited number of studies have investigated the effects of brand orientation and knowledge creation process together on organisational performance. The studied tourism entrepreneurs exhibit low involvement in branding activities and knowledge creation according to government of Malaysia sources. The significance of brand orientation and knowledge creation process for improving the organisational performance of tourist resorts remains inconclusive. For this study, empirical data was drawn from 322 tourist resorts in Malaysia. The hypothesised relationships are analysed using structural equation modelling (SEM). The results show that brand orientation and knowledge creation process have a positive and significant effect on organisational performance whereas knowledge creation process partially mediates brand orientation and organisational performance. We propose higher involvement of tourism entrepreneurs in knowledge sharing sessions to develop distinctive brands to attract customers, which will in turn improve organisational
\end{abstract}

(C) Asian Academy of Management and Penerbit Universiti Sains Malaysia, 2019. This work is licensed under the terms of the Creative Commons Attribution (CC BY) (http://creativecommons. org/licenses/by/4.0/). 
performance. The top-down management approach in instituting branding activities remains pervasive in tourist resorts in Malaysia's high-power distance society.

Keywords: brand orientation, knowledge creation process, organisational performance, tourism, entrepreneur

\section{INTRODUCTION}

Malaysia is regarded as an emerging economy with a large middle-income population. Since gaining independence from the British in 1957, the economy has grown by an average of $6.5 \%$ per annum. The tourism industry contributes significantly to the Malaysian economy, accounting for about 15\% of Malaysia's total employment and $12 \%$ of its gross domestic product (GDP). Tang and Tan (2015) found that economic growth, tourism, and other determinants are cointegrated. Specifically, tourism has a positive impact on Malaysia's economic growth both in the short and long run. The sector is one of these new key economic areas (NKEAs) in the New Economic Model unveiled in 2010.

There are limited studies in the branding and knowledge management literature concerning the combined effect of brand orientation and knowledge creation process on organisational performance. Extant studies have mostly focused on examining the constraints of physical resources such as funds and service production assets that lead to poor organisational performance (Liow, 2017; Set, 2013). More recent interest in harnessing internally generated capabilities such as branding efforts and knowledge creation activities by businesses has been classified as the most accessible organisational asset (Liow, 2017; Thomas, Shaw, \& Page, 2011). However, the empirical upshots of the scenarios in the Malaysian context are not resolutely established in branding and knowledge management literature and in the field of tourist resorts. Past Malaysian studies have focused on the effects of brand image on customer satisfaction (Lahap, Ramli, Said, Radzi, \& Zain, 2016) and the brand perceptions of Malaysian tourists (Kim, Im, \& King, 2015). Efforts of recent empirical accommodation-based studies to evaluate knowledge creation process activities have mostly been undertaken for enhancing web features (Ayob, WilsonEvered, \& McGrath, 2017) and applying Web 2.0 or social networking sites (Xin, Ramayah, Soto-Acosta, Popa, \& Teoh, 2014).

A review of Malaysian knowledge management literature reveals a dearth of studies on tourist resorts that integrate knowledge creation activities into their businesses for enhancing organisational performance outcomes. Most past studies were usually set in developed nations from the European and Northeast 
Asian regions (Liow, 2017; Set, 2013). Nevertheless, firms' branding efforts and knowledge creation processes can be context-specific as opposed to universally acceptable. Therefore, the evidence drawn from developing nations can contribute significantly to branding and knowledge management literature due to the varying socio-economic conditions and political governance as well as forms of market competition. Marketers in developing nations face a stigma as compared to the developed nations in promoting their products, in which the former struggles to overcome the perceived markets' image of their inferior image since it is not "made-in" and "made for" the developed nations (Gürhan-Canli, Sarial-Abi, \& Hayran, 2018; Herstein, Berger, \& Jaffe, 2014; Rottig \& de Oliveira, 2019). Despite intense efforts by the governments in the developing nations to change the market's perception into forming a favourable image of their product and services, they are unable to break these intangible market barriers. The markets' belief that the lower socio-economic standing of the developing nations as compared to their developed counterparts will result in low branding and knowledge management activities and in turn, less satisfying products and services (Herstein et al., 2014; GürhanCanli et al., 2018; Rottig \& de Oliveira, 2019). Consequently, evidence from such contexts offer unique insight in addition to views from developed tourism-based economies, where the results of firms' strategic practices and outcomes appear almost nuanced.

To address the preceding research gaps, this study aims to examine the relations between brand orientation, knowledge creation process, and organisational performance. To do this, the differential roles of two internally generated capabilities are conceptualised, namely organisational branding and knowledge creation activities to enhance organisational performance rather than focusing on physical assets. Since there is evidence that businesses are circumventing their physical resource constraints in order to succeed (Liow, 2017; Thomas et al., 2011), further contribution is made to branding and knowledge management literature as well as the field of tourist resorts by presenting empirical evidence from the context of a developing nation in the Southeast Asian region.

\section{TOURIST RESORTS IN MALAYSIA}

Tourist resorts play an important role in the tourism industry. These include selfcontained and commercial golf resorts, island resorts, hill resorts, lake resorts, beach resorts, spa resorts, and theme park resorts. Tourist resorts offer a range of services, including accommodation, food, entertainment, and recreation services (e.g., sports, jungle trekking, educational field trips) and/or facilities for meetings, incentives, conventions and exhibitions (MICE). 
In Malaysia, tourist resorts range from one-star to five-star accommodation premises. They are patronised for various reasons - natural or built beauty, historical significance, cultural heritage value, education, business, and leisure. For example, Strawberry Park Resort in the Cameron Highlands is popular with holiday makers, golfers, and business travellers. The resort hosts a neo-Tudor style accommodation premise within lush natural surroundings and a golf resort. Mutiara Taman Negara Resort, a popular tourist resort in the state of Pahang, boasts a wide species of flora and fauna and has basic accommodation for nature lovers and trekkers. Perhentian Island Resort, which is located in the state of Terengganu, offers accommodation with a beach front that appeals to visitors who enjoy sun, sea, and sand recreation activities. The 1881 Chong Tian Cultural Hotel offers an exclusive combination of culture, history, and luxury in George Town, Pulau Pinang, one of Malaysia's UNESCO sites. The town is laden with museums that narrate the stories of immigrants and merchants from China who made their fortune in the 19th century.

The globalisation of markets has intensified efforts by governments around the world to attract high-yield visitors. Tourism accommodation infrastructure has also become more sophisticated over the years, and tourists are spoilt for choices due to a large number of countries with similar offerings in terms of natural resources, infrastructure, traditions, and cultures. This phenomenon poses a challenge to Malaysia in attracting tourists.

Indeed, the globalisation effects have resulted in a growing number of domestic and foreign-owned hotels and resorts setting up business in the country. According to the Department of Statistics, Malaysia (2018), 66,414 or 13\% of all tourism establishments in Malaysia are classified under the accommodation sector, including tourist resorts, which saw a growth of $6.4 \%$ between 2010 and 2015 . Investment in fixed assets grew by $10.5 \%$ of nearly RM220 billion and there was an increase of $10.3 \%$ in the value added of RM166 billion in the same period. The number of workers also grew by $4.4 \%$ and employment was offered to 2.5 million workers who have seen a $11.2 \%$ rise in salaries and wages amounting to RM51 billion. Among the 13 Malaysian states, $60 \%$ of the value added is generated from the capital city, Kuala Lumpur and the Federal Territory, followed by Johor (7\%) and Pulau Pinang (5.5\%). Keeping the tourism industry viable is important to preserve employment and sustain economic growth.

In this study, "tourism entrepreneurs" are referred to as owner-managers in charge of managing daily tourist resort operations. A tourism entrepreneur is someone who possesses in-depth knowledge of the firm's operations and is responsible for the organisational performance. Generally, they mostly represent the organisation since they are the primary decision-makers. Therefore, the empirical data for this 
study was drawn from the perspectives of tourism entrepreneurs at 322 tourist resorts in Malaysia.

\section{LITERATURE REVIEW AND HYPOTHESIS DEVELOPMENT}

\section{Underpinning Theories}

The resource-advantage theory classifies brand orientation demonstrated by owners-managers as an internal organisational resource that enables a business to develop strategies and gain a competitive advantage (Hunt, 1995; Hunt \& Morgan, 1995; Urde, Baumgarth, \& Merrilees, 2013). Knowledge is tacit and has transferability issues (Hunt \& Arnett, 2006). To deal with the dynamic business environment, businesses need to engage in knowledge creation process to transfer the brand orientation activities into effective strategies for enhancing organisational performance (Nonaka \& Konno, 1998). The knowledge creation theory describes that knowledge is created through the dynamic interaction linking the internal stakeholders (employees) and external stakeholders (suppliers, competitors, media, and government). The tacit knowledge and the external knowledge gained through the synergistic branding activities and knowledge creation process enable owners-managers to organise into effective company practices institutionalised through a spiral of socialisation, externalisation, combination, and internalisation (SECI) processes (Gold, Maholtra, \& Segars, 2001; Nonaka \& Konno, 1998). By harnessing the new-found knowledge, owners-managers are able to respond with marketing tactics and new products that are better than their competitors', and in turn advances its organisational performance (Gold et al., 2001; Nonaka \& Konno, 1998; Nonaka \& Toyama, 2005).

To this end, some works have emphasised the needs of brand orientation and knowledge creation process that offer a competitive advantage for businesses across multiple study contexts. Following from the former discourses, we outline brand orientation as an antecedent or a predictor and examines its relationships on knowledge creation process and organisational performance of tourist resorts in a developing tourism-based nation, namely Malaysia.

\section{Organisational Performance of Tourist Resorts}

Determining suitable organisational performance measurements for accommodation sector businesses including tourist resorts has been conflicting among scholars over the years (Liow, 2017). At times, it seems suitable to adopt perceptionbased measurement in the accommodation sector that commercialises intangible 
experiences (Hariandja, 2011). Other scholars have proposed incorporating financial and non-financial measures (e.g., Haber \& Reichel, 2005). There are scholars who have expressed difficulty measuring the optimisation of internal capability resources, since retrieving third-party certifiable objective performance data is almost impossible (Chokesikarin, 2014; Liow, 2017). Liow and Yeow (2015) noted that respondents' interpretations correspond closely with external secondary performance data and objective performance measurement. The same approach has been employed in several studies in the accommodation industry (e.g., Al-Nuiami, Idris, Al-Ferokh, \& Abu Joma, 2014; Chen, Hsu, \& Tzeng, 2011; Chokesikarin, 2014; Tajeddini, 2010; Wilkins, 2010; Zeglat \& Zigan, 2014). Thus, a firm-level analysis is undertaken in this study to measure the organisational performance of tourist resorts based on tourism entrepreneurs' perceptions. In addition, the competitor comparison approach is utilised, as this approach blends well with the product differentiation strategy (Porter, 1985). The organisational performance of tourist resorts is measured in this study by comparing with other market players in the accommodation industry.

\section{Brand Orientation and Organisational Performance}

Brand orientation is an identity-driven approach that differentiates a firm through brand-building activities (Urde et al., 2013). These brand building activities include developing a unique corporate brand identity, expanding brand portfolios, instituting brand communications management, and estimating their own brand valuation (Aaker, 1991; de Chernatony \& Riley, 1998; Keller, 2000). By focusing on each of these aspects, an organisation is able to effectively identify whether their own brand vision and strategies are aligned with consumers' brand perceptions. Sustainable organisational performance can be recognised through evaluations made of the relative value of a brand in the minds of consumers. Organisations in turn, create brands that resonate with stakeholders' expectations in terms of tangible and intangible benefits. Studies on brand orientation have also expanded into the non-profit sector. Ewing and Napoli (2005) developed a brand orientation scale for churches that consists of three dimensions: brand interaction, brand affect, and brand orchestration. Brand interaction evaluates the degree to which an organisation initiates a dialogue with primary stakeholders through its brand names and marketing campaigns and uses the market feedback to create superior value to stakeholders. Brand affect evaluates the extent to which an organisation understands to which they are liked or disliked and what about, that is whether organisations are in favour of having a brand logo, visible brand designs, and corporate design that help to constitute favourable stakeholders' perceptions. Brand orchestration measures the degree to which an organisation's ability to which the brand portfolio is structured into integrated marketing campaigns that 
deliver consistent messages such as instilling trust in the brand and stakeholders understanding the symbolic value of the brand. We contend that such principles are equally applicable for-profit organisations since the three brand orientation dimensions are broadly captured in Keller's (2000) brand report card.

An evaluation of branding literature from the past two decades has shown a lack of research on the role of tourism entrepreneurs' brand orientation and the effect on enhancing the overall organisational performance in Southeast Asia (Liow, 2017). Extant studies have primarily researched organisational branding efforts as a single market capability. In other cases, past scholarly work has examined its relationship with internal sales departmental goals and customer relationship management. For instance, in the case of Malaysia, Ismail, Muhammad, Yusoff, and Shariff (2016) investigated the relations between hotel brand identity and food quality in restaurants. Lahap et al. (2016) revealed that brand image has a positive effect on customer satisfaction in the Malaysian hotel industry. Similarly, according to primary data from 108 subsidiaries of multinational enterprises operating in the Commonwealth Caribbean region, Boso, Carter, and Annan (2016) found that brand orientation has a positive influence on sales performance. Casidy, Wymer, and O'Cass (2018) found some evidence that the hotel brand performance of American hotels is enhanced by forging a brand relationship in the customers' minds. In the same vein, Ciunova-Shuleska, Palamidovska-Sterjadovska, Osakwe, and Omotoso (2017) demonstrated a significant relationship between brand orientation and the financial performance of organisations in the hospitality industry in the Republic of Macedonia. In Finland, Laukkanen, Tuominen, Reijonen, and Hirvonen (2016) verified that market orientation does improve the financial performance of small firms in the hospitality industry. In this regard, a positive and significant effect of brand orientation on organisational performance is expected in the following hypothesis:

H1: Brand orientation has a positive and significant effect on organisational performance.

\section{Brand Orientation and Knowledge Creation Process}

It is useful for organisations to gather, retain, incorporate, and create new knowledge as a means to remain competitive (Li, Huang, \& Tsai, 2009; Nonaka, 1994; Nonaka \& Konno, 1998). According to Nonaka and Takeuchi (1995), knowledge creation involves a series of self-transcendental processes called SECI that facilitate knowledge conversion and transformation. Marketing activities and new product development start with the socialisation process, which involves face-to-face meetings, brainstorming sessions, and the grapevine. Externalisation triggers the 
understanding of different organisational stakeholders, leading to the formulation of marketing and product concepts ( $\mathrm{Li}$ et al., 2009). The combination process involves screening the concepts before tangible efforts are made in production and marketing campaigns ( $\mathrm{Li}$ et al., 2009). Internalisation refers to the conversion of explicit knowledge to tacit knowledge, where knowledge is internalised and formalised into standard operating procedures (Li et al., 2009).

Travel intermediaries can work together with employees at tourist resorts to harness collective knowledge and better serve their customers (Acs, Brooksbank, O'Gorman, Pickernell, \& Terjesen, 2012; Thomas et al., 2011). Similarly, tourism entrepreneurs can enhance brand image through constant sharing and reflection on work processes, products and services with their employees (Thomas et al., 2011). Knowledge creation holds that organisational culture is created through continuous dialogue ( $\mathrm{Li}$ et al., 1998). Hotel branding that expresses a culture with emphasis on service quality is likely to help continuously gather knowledge for improving hotel guests' experience. Manthiou, Kang, Sumarjan, and Tang (2016) studied Malaysian international hotel chains and found that satisfied and loyal hotel guests tend to associate themselves with the hotel brand. These hotel guests in turn spread their knowledge of the hotel brands and what the hotels have to offer to their social circles. On this basis, it is useful to investigate the effect of brand orientation on knowledge creation process. The following hypothesis is therefore formed:

$\mathrm{H} 2$ : Brand orientation has a positive and significant effect on knowledge creation process.

\section{Knowledge Creation Process and Organisational Performance}

Knowledge management literature has expanded in the last 20 years. A review of past scholarly work in this field suggests that most research has been conducted on large organisations and in developed nations (Liow, 2017). Knowledge creation process is an emerging topic in this field due to today's dynamic and competitive world. The concept deviates from the view that tourism entrepreneurs know it all. To achieve superior organisational performance, the tourism entrepreneur is dependent on the knowledge supplies that are transformed and embedded into the organisation's daily operations. This is where the tourism entrepreneur works as an arbitrator who chooses which knowledge applications will be effective for organisational use. Knowledge applications include online travel booking platforms and corporate websites for public use (Liow, 2017). Knowledge applications are shaped through employee narrations, industry data gathered by tourism-based government agencies, and feedback from customers and travel intermediaries. 
Knowledge creation enables firms to transmute the knowledge pool and incorporate the knowledge into business operations that enhance firm performance ( $\mathrm{Li}$ et al., 2009). Giampaoli, Ciambotti, and Bontis (2017) found a positive link between top Italian firms' knowledge management practices and the firms' financial and organisational performance. Specifically, social interactions among the travel and tourism public enable the transfer and dissemination of knowledge, leading to the formulation of follow-up strategies (Tsiotsou \& Ratten, 2010) and economic opportunities for firms (Acs et al., 2012). Furthermore, the increasing number of prosumers and the disintermediation and re-intermediation of travel wholesalers and travel agents have disrupted how knowledge is gathered, transferred, and received at tourist destinations (Tsiotsou \& Ratten, 2010). The following hypothesis is proposed to examine whether the organisational performance of tourist resorts can be improved by undertaking knowledge creation process:

H3: Knowledge creation process has a positive and significant effect on organisational performance.

\section{Knowledge Creation Process as a Mediator}

The brand orientation-organisational performance relationship may be more complicated than it seems. In particular, knowledge creation process can serve as an intervening variable between brand orientation and organisational performance. Increasingly, more studies are examining the mediation effect of a few variables in the tourism and hospitality industry, such as: the influence of organisational effectiveness on knowledge management implementation (Yang \& Wan, 2004), a collaborative culture on knowledge sharing (Yang, 2010), and individual attitudes on organisational knowledge sharing (Yang, 2008). Sigala and Chalkiti (2007) studied the performance of Greek hotels and claimed direct impacts of tacit knowledge externalisation and utilisation on firm outcomes. Muhonen, Hirvonen, and Laukkanen (2017) found that brand orientation enhances the brand identity of small and medium enterprises. They investigated whether brand identity mediates the relationship between brand orientation and brand performance in Finnish small and medium enterprises. Terglav, Ruzzier, and Kase (2016) investigated the mediating role of employee brand management, psychological contract, and employee-brand fit in the leadership mind sets of European hotel chains and employee brand commitment. The mediators in Terglav et al.'s (2016) study were close forms of the SECI processes in Nonaka and Takeuchi's (1995) study relating to brand knowledge. For this study, the following hypothesis is formulated:

H4: Knowledge creation process mediates brand orientation and organisational performance. 


\section{RESEARCH METHODOLOGY}

\section{Sample, Sampling, and Data Collection}

Data was collected in the 11 states of West Malaysia and 2 states of East Malaysia. According to the Department of Statistics, Malaysia (2018), there are a total of 66,414 tourism establishments in the accommodation sector. Since there is no consolidated database solely on tourist resorts in Malaysia, the list of tourist resorts for this study was extracted from one of the most popular online booking websites in Malaysia, Booking.com, that features 410 tourist resorts. Hair, Black, Babin, and Anderson (2010) claim the most acceptable way for determining the sample size is 10:1 ratio (that is a target of 340 cases for this study) and a sample should be more than 100 before proceeding with factor analysis. The targeted sample size was at least 300 cases so as to offer a good representation of tourist resorts in Malaysia with 95\% confidence interval as recommended by Saunders, Lewis, and Thornhill (2012). Trained research enumerators proficient in English and the national language Bahasa Malaysia were briefed with a thorough description of the tourist resorts and the questionnaire items relating to the demographic profile and research variables.

The purposive sampling approach was applied to ensure that qualified respondents were identified from the tourist resort business, resulting in a representative sample to help answer the research objectives of this study. The targeted respondents were tourism entrepreneurs or owner-managers who possess in-depth knowledge of tourist resort operations and are accountable for the overall organisational performance. They are the main decision-makers who represent the tourist resorts in their charge.

The research enumerators approached tourism entrepreneurs. Those who showed keen interest to participate were briefed on the survey purpose and promised anonymity preservation. The drop and collect procedure was instituted. The participants received a hardcopy of the survey questionnaire, which was collected one to two days later.

A total of 370 questionnaires were distributed from December 2017 to May 2018 and 343 were filled out and returned. From the returned questionnaires, 21 unusable responses were identified and omitted from the sample. The final sample size was 322 for a response rate of $87 \%$. The response rate is high for this feminine society. Malaysia scores an intermediate 50 out of 100 for the masculinity dimension (Hofstede Insights, 2018). The tourism entrepreneurs in this feminine society were 
prone to respond to the survey, since they were able to have face-to-face contact with the local enumerators. The drop and collect procedure was effective because Malaysians tend to be conservative and it is a society that expresses humility and does not like confrontations. Therefore, most tourism entrepreneurs participated voluntarily in the survey with little need for persuasion by the local enumerators.

\section{Measurement}

The data was based on the perceptions derived from tourism entrepreneurs managing tourist resorts in Malaysia. All item measurements for the three constructs are valid and reliable for the service-based industry. Each dimension in this study is measured with the 5-point Likert scale. Both brand orientation and knowledge creation process constructs applied descriptors " $1=$ strongly disagree" to " $5=$ strongly agree". The brand orientation construct was measured with Ewing and Napoli's (2005) scale that consists of 14 items. The items in this measurement scale have been adopted in studies on services offered in churches (Mulyanegara, 2010) and small hotels (Peters, Pfurtscheller, Wong, \& Kraus, 2010). This construct has three sub-constructs: brand interaction (INT), brand affect (AFF), and brand orchestration (ORC). Knowledge creation process construct was measured with Sabherwal and Becerra-Fernandez' (2003) scale that encompasses 16 items, which was previously adopted in Li et al.'s (2009) study partly on the service-based industry. This scale has 4 sub-constructs: $\mathrm{S}=$ socialisation, $\mathrm{E}=$ externalisation, $\mathrm{C}=$ combination, and $\mathrm{I}=$ internalisation. Organisational performance was measured using two operational items (occupancy rate and revenue per available room) and two financial performance items (return on capital and gross operating profit). The measurement items were adapted from Zeglat and Zigan's (2014) scale as applied in their study on large hotels. A threeyear period was selected to compare the year-to-year organisational performance results of each tourist resort against its competitors. A descriptor $(1=$ much worse to $5=$ much better) was used to ease the comparisons with the competitors.

\section{RESULTS}

\section{Respondent Profile}

Of the 322 respondents, $40 \%$ were female and $60 \%$ male. A majority ( $81 \%)$ of the respondents were between 31 and 50 years old; $69 \%$ had tertiary education with $35 \%$ reportedly having a hospitality and tourism-related qualification, and $27 \%$ indicating they have a business-related qualification. 
Of the tourist resorts, $46 \%$ experienced an average of $61 \%$ to $80 \%$ annual occupancy rate. Seventy-nine percent (79\%) of the respondents reported an average tourist spending between RM400 and RM600 per visit that covers an average stay length of four days and three nights. The tourism entrepreneurs cited that the primary purposes of visits to the tourist resorts are recreational (39\%) and for meetings, incentives, expositions, and exhibitions (MICE) (28\%).

\section{Exploratory Factor Analysis and SEM Results}

Primary data was collected in this study to investigate the effects of brand orientation and knowledge creation process on organisational performance. The combination of the three research variables is novel and to our knowledge, is not commonly applied at least in the Malaysian tourism industry context. The authors therefore perform exploratory factor analysis (EFA) - an item deletion technique - to ascertain the suitability of the variables in addressing the research aims of this study (Bollen, 1989; Byrne, 2010; Holmes-Smith, Coote, \& Cunningham, 2006). To estimate the factor loadings and communalities, it is recommended to perform EFA on the three constructs: brand orientation, knowledge creation process, and organisational performance all together (Green, Tonidaandel, \& Cortina, 2016). Varimax rotation is applied in the present study, which is a function that enables high item loading on one factor and small item loading on the rest of the factor solutions (Hair et al., 2010).

The brand orientation construct is measured with Ewing and Napoli's (2005) scale that consists of 14 items. In the specified Ewing and Napoli's (2005) first-order, three-factor structure model; structural equation modelling (SEM) was exercised to perform a confirmatory factor analysis (CFA). The model comprised of three latent variables (interaction, affect, and orchestration). The Ewing and Napoli's (2005) model based on the criteria proposed by Bentler (1990), produced an acceptable fit to the data that explains the second order construct for brand orientation. In this study, as reported in Table 1, the results with the maximum likelihood using varimax rotation are a three-dimensional construct (INT: factor 5; AFF: factor 3; and ORC: factor 6) consisting of 9 (out of 14) items with a factor loading above 0.5 . The Cronbach's alpha of the brand orientation construct exceeds 0.70 , establishing the construct's reliability (Hair et al., 2010).

Knowledge creation process construct is measured with Sabherwal and BecerraFernandez's (2003) scale that encompasses 16 items. This study adopts the SECI model by Nonaka (1994) to examine the second order construct of knowledge creation process for the following three reasons. Firstly, the SECI model is one of the knowledge creation theories that examines the interrelationships between 
tacit and explicit knowledge. Secondly, the SECI model encompasses not only knowledge transfer but also knowledge creation. Thirdly, this model has been applied in many research areas such as new product development and organisational learning (Lee \& Choi, 2003; Nonaka \& Toyama, 2005). In this study, the results with maximum likelihood using varimax rotation establish a three-dimensional construct with 12 (out of 16) items retained with acceptable factor loading above 0.5 (Table 1). The 12 items load highly on 3 factors: 3 items each onto factor 7 $(\mathrm{S}=$ socialisation $)$, factor $4(\mathrm{E}=$ externalisation $)$, and factor $1(\mathrm{C}=$ combination and I = internalisation). The Cronbach's alpha values are greater than the minimum threshold of 0.7 , confirming the construct's reliability.

The organisational performance construct was measured using two operational items (FC1: occupancy rate; and FC3: revenue per available room) and two financial performance items (FC2: gross operating profit; and FC4: return on capital) as adapted from Zeglat and Zigan's (2014) scale. A three-year period was selected to compare the year-to-year organisational performance results of a tourist resort against its competitors, which received a descriptor $(1=$ much worse to $5=$ much better) to ease comparisons with competitors. The EFA results reveal that the organisational performance construct is unidimensional. The Cronbach's alpha value is 0.842 , exceeding the minimum threshold of 0.70 (Table 1 ).

This study is based on self-reported data, therefore there is a risk of common method bias. A Harman's single test was performed as suggested by Hair et al. (2010), and the test revealed there are altogether seven factors with eigenvalues above 1 . One of these factors explained $16 \%$ of the total explained variance, therefore there is no single factor that explained most of the variance. Thereby, common method bias is not likely to be a severe problem in this study.

Two-step SEM was applied next. The first step involved CFA that validates the measurement model consisting of three constructs: brand orientation, knowledge creation process, and organisational performance to determine the proposed model fit. In the second step, the structural model was applied to test the hypotheses. Maximum likelihood estimation was performed using Analysis of Moment Structures (AMOS) 22. 


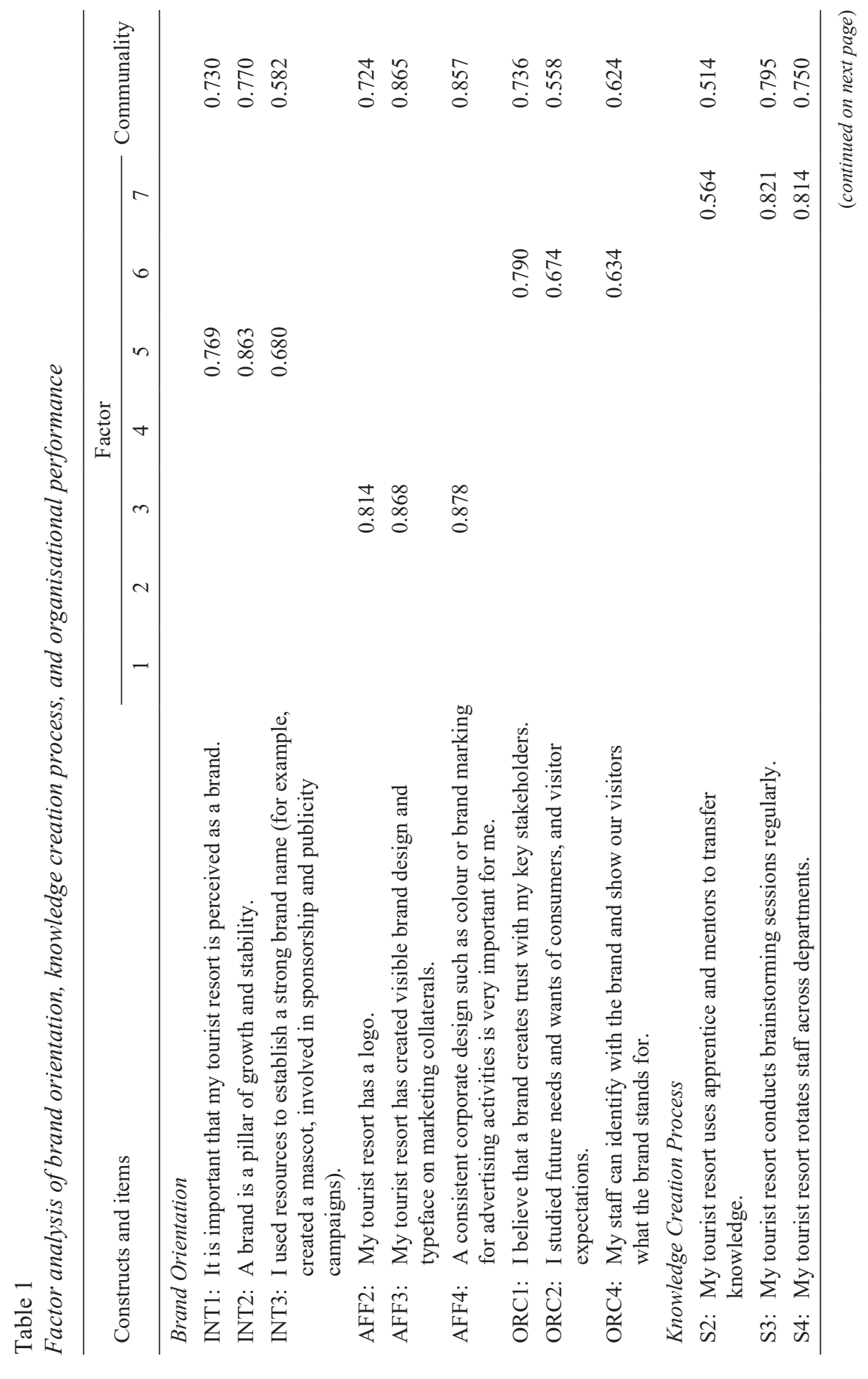


Brand Orientation, Knowledge Creation, and Performance

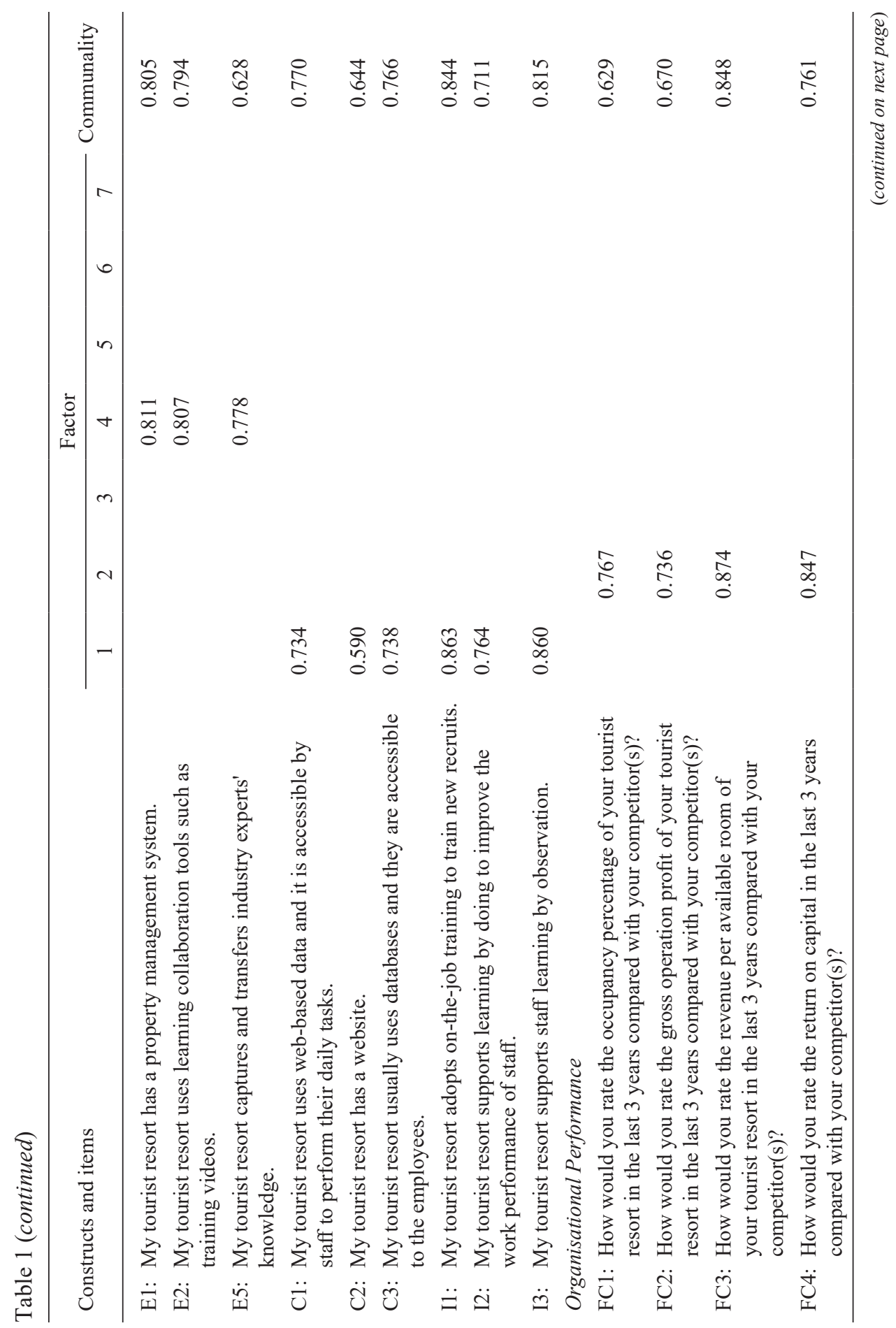


Melissa Li Sa Liow et al.

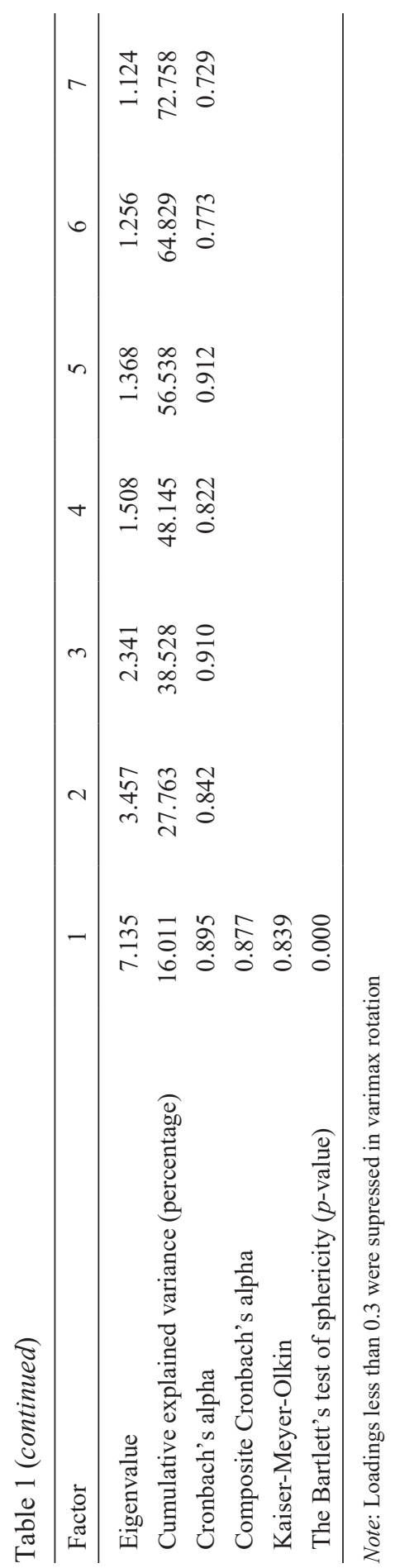




\section{Step 1: Model fit}

CFA was applied using AMOS 22 to verify the factor structure of the variables. The results show that the model fit can be accepted [Root Mean Square Error of Approximation (RMSEA) $=0.047$, Goodness of Fit Index $(\mathrm{GFI})=0.900$, Comparative Fit Index $(\mathrm{CFI})=0.964$, Tucker-Lewis Index $(\mathrm{TLI})=0.959$, Normed Fit Index $(\mathrm{NFI})=0.919$, Chi-sq/df $=1.724]$. The model's unidimensionality, validity, and reliability were also tested. As shown in Table 2, the unidimensionality condition is met, since the measurement items correspond to items with a factor loading above 0.50 (Hair et al., 2010). Construct validity is also achieved because the fitness indices for brand orientation, knowledge creation process, and organisational performance indicate good model fit. Convergent validity is demonstrated with an average variance extracted value (AVE) for each construct and sub-construct greater than 0.5. The composite reliability (CR) for each construct and sub-construct is greater than 0.60, suggesting that the measurement model is reliable (Hair et al., 2010).

Table 2

CFA results

\begin{tabular}{llccc}
\hline Sub-construct & Item & Factor loading & CR $>0.6$ & AVE $>0.5$ \\
\hline Brand affect & AFF1* & - & 0.916 & 0.787 \\
& AFF2 & 0.737 & & \\
& AFF3 & 0.961 & & \\
& AFF4 & 0.946 & & \\
& AFF5* & - & & \\
& AFF6* & - & & \\
Brand orchestration & ORC1 & 0.537 \\
& ORC2 & 0.649 & 0.775 & \\
& ORC3* & - & & \\
& ORC4 & 0.768 & & 0.519 \\
Brand interaction & INT1 & 0.862 & 0.760 & \\
& INT2 & 0.649 & & \\
& INT3 & 0.627 & & \\
\hline
\end{tabular}

(continued on next page) 
Melissa Li Sa Liow et al.

Table 2 (continued)

\begin{tabular}{|c|c|c|c|c|}
\hline Construct & Sub-constructs & Factor loading & $\mathrm{CR}>0.6$ & AVE $>0.5$ \\
\hline \multirow[t]{3}{*}{ Brand orientation } & Brand affect & 0.673 & 0.769 & 0.528 \\
\hline & Brand orchestration & 0.796 & & \\
\hline & Brand interaction & 0.705 & & \\
\hline \multirow[t]{4}{*}{ Socialisation } & S1r* & - & 0.770 & 0.532 \\
\hline & $\mathrm{S} 2$ & 0.580 & & \\
\hline & S3 & 0.849 & & \\
\hline & S4 & 0.735 & & \\
\hline \multirow[t]{5}{*}{ Externalisation } & E1 & 0.932 & 0.849 & 0.663 \\
\hline & E2 & 0.906 & & \\
\hline & $\mathrm{E} 3 *$ & - & & \\
\hline & $\mathrm{E} 4 *$ & - & & \\
\hline & E5 & 0.548 & & \\
\hline \multirow[t]{4}{*}{ Combination } & $\mathrm{C} 1$ & 0.906 & 0.909 & 0.769 \\
\hline & $\mathrm{C} 2$ & 0.776 & & \\
\hline & $\mathrm{C} 3$ & 0.941 & & \\
\hline & $\mathrm{C} 4 *$ & - & & \\
\hline \multirow{3}{*}{ Internalisation } & I1 & 0.945 & 0.917 & 0.786 \\
\hline & I2 & 0.817 & & \\
\hline & $\mathrm{I} 3$ & 0.893 & & \\
\hline Construct & Sub-constructs & Factor loading & $\mathrm{CR}>0.6$ & $\mathrm{AVE}>0.5$ \\
\hline \multirow{4}{*}{$\begin{array}{l}\text { Knowledge creation } \\
\text { process }\end{array}$} & Socialisation & 0.631 & 0.804 & 0.508 \\
\hline & Externalisation & 0.673 & & \\
\hline & Combination & 0.789 & & \\
\hline & Internalisation & 0.748 & & \\
\hline Construct & Item & Factor loading & $\mathrm{CR}>0.6$ & AVE $>0.5$ \\
\hline \multirow{4}{*}{$\begin{array}{l}\text { Organisational } \\
\text { performance }\end{array}$} & $\mathrm{FC} 1$ & 0.643 & 0.868 & 0.627 \\
\hline & $\mathrm{FC} 2$ & 0.703 & & \\
\hline & $\mathrm{FC} 3$ & 0.965 & & \\
\hline & $\mathrm{FC} 4$ & 0.818 & & \\
\hline
\end{tabular}

Notes: $\mathrm{CR}=$ composite reliability; AVE = average variance extracted.

Item S1r is a reverse coding item. The items* were deleted after EFA. No further items were deleted during CFA. 
Discriminant validity demonstrates that a measure is different from another or does not correlate (Hair et al., 2010). The discriminant validity is assessed by computing the square root of the AVE values. It is found that all AVE values are greater than the correlations between each construct and other constructs, showing evidence of discriminant validity (Table 3).

Table 3

Discriminant validity

\begin{tabular}{lccc}
\hline Construct & $\begin{array}{c}\text { Brand } \\
\text { orientation }\end{array}$ & $\begin{array}{c}\text { Knowledge creation } \\
\text { process }\end{array}$ & $\begin{array}{c}\text { Organisational } \\
\text { performance }\end{array}$ \\
\hline Brand orientation & $\mathbf{0 . 7 2 7}$ & & \\
Knowledge creation process & $0.371^{* * *}$ & $\mathbf{0 . 7 1 3}$ & $\mathbf{0 . 7 9 2}$ \\
Organisational performance & $0.345^{* * *}$ & $0.406^{* * *}$ & $\mathbf{0}$ \\
\hline
\end{tabular}

Note: The diagonal elements in bold in the "correlation of constructs" matrix is the square root of AVE. ${ }^{* * *} p<0.001$.

\section{Step 2: Estimating the structural model}

The structural model was estimated using AMOS 22. The SEM results establish good model fit to the data $(\mathrm{RMSEA}=0.047$; GFI $=0.896$; CFI $=0.960$; $\mathrm{TLI}=0.955 ; \mathrm{NFI}=0.911 ; \mathrm{Chi}-\mathrm{sq} / \mathrm{df}=1.721)$. The correlation coefficient is below 0.85 , indicating that the exogenous constructs brand orientation and knowledge creation process are not redundant.

Figure 1 includes the standardised path coefficient, path significance, and variance explained for each path or $\mathrm{R}^{2}$. Evidently, brand orientation explains $14 \%$ of the variance in knowledge creation process. The brand orientation and knowledge creation process constructs explain $21 \%$ of the variance in organisational performance, suggesting a moderate effect of both constructs (Cohen, 1988).

$\mathrm{H} 1, \mathrm{H} 2$, and $\mathrm{H} 3$ are supported. The path in $\mathrm{H} 1$ is positive and significant $(\beta=0.226$, $p<0.01)$. Brand orientation has a positive and significant effect on knowledge creation process $(\beta=0.371, p<0.01)$; therefore, $\mathrm{H} 2$ is supported. The more brandorientated a tourist resort is, the more committed their tourism entrepreneurs are to knowledge creation process. Additionally, knowledge creation process is found to have a positive and significant effect on organisational performance ( $\beta=0.322, p<0.001)$; hence, H3 is supported. 
The indirect effect $(0.119, p<0.01)$ is smaller than the direct effect $(0.226$, $p<0.01$ ). This result indicates a potential partial mediating role of knowledge creation process since all three paths (1) brand orientation to organisational performance, (2) brand orientation to knowledge creation process, and (3) knowledge creation process to organisational performance are significant. Alternatively, for verifying the mediation test results, Awang (2015) suggested comparing the value of the direct effect between the independent and dependent variables in a single model on its value when the mediator enters the model. If the value is reduced when the mediator is included, partial mediation occurs. The path of brand orientation to organisational performance in a single model is significant $(\beta=0.342, p<0.01)$. The value is reduced when knowledge creation process (the mediator) enters the model $(\beta=0.119, p<0.01)$. Therefore, the results reveal that partial mediation occurs. According to Awang (2015), with partial mediation, the independent variable (brand orientation) has both direct and indirect effects on the dependent variable (organisational performance). The direct effect is not mediated whereas the indirect effect is transmitted through the mediator variable, knowledge creation process. Hence, $\mathrm{H} 4$ is supported.

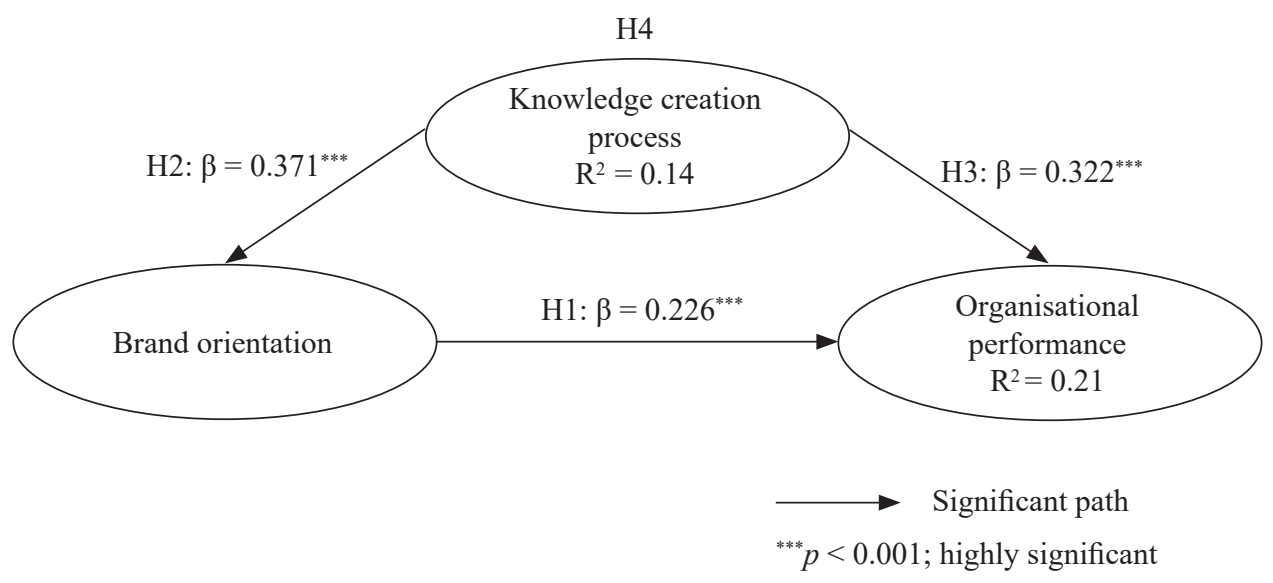

Figure 1. Path analysis model

\section{DISCUSSION}

\section{Linking the Results to the Research Objectives and Past Studies}

This study attempts to investigate the effects of brand orientation and knowledge creation process on organisational performance with particular reference to tourist resorts in Malaysia. The results show that brand orientation and knowledge creation 
process have a positive and significant effect on organisational performance. The study reveals the superior role of brand orientation and knowledge creation process in enhancing the organisational performance of tourist resorts. In congruence with Boso et al. (2016), Casidy et al. (2018), Ciunova-Shuleska et al. (2017), Ismail et al. (2016), and Laukkanen et al. (2016), branding orientation activities are found to be an essential asset for enhancing the organisational performance of tourist resorts. Our findings emphasise the importance of knowledge creation process for tourist resorts in transmuting the knowledge pool and incorporating knowledge into business operations that enhance organisational performance (Li et al., 2009). Thus, for organisations with higher involvement in knowledge creation it is easier to marshal the interrelated socialisation, externalisation, combination, and internalisation activities in their organisational activities to optimise organisation performance. The current study findings lend empirical support on the importance of transferring and disseminating knowledge that leads to the formulation of follow-up strategies (Tsiotsou \& Ratten, 2010) and economic opportunities for firms (Acs et al., 2012; Giampaoli et al., 2017).

The results from this study also reveal that knowledge creation process partially mediates the effect of brand orientation on organisational performance, which demonstrates partial support for past empirical studies (Terglav et al., 2016; Yang, 2008, 2010; Yang \& Wan, 2004). The results offer more support to Sigala and Chalkiti's (2007) study on the direct effects of tacit knowledge externalisation and utilisation and its impacts on firm outcomes. The partial significance results could be due to the heterogeneity of the characteristics of the tourism sectors, and that generalisations cannot simply be made as in the case of tourist resorts (Acs et al., 2012; Thomas et al., 2011; Tsiotsou \& Ratten, 2010). The slight deviation in results supports Liow (2017) and Set (2013), who claimed that more research is needed since there is a lacuna of studies in the Southeast Asian region in contrast to past research mostly set in developed nations.

One of the implications of this study is that mere access to physical resources does not adequately help enhance organisational performance. In congruence with Liow (2017) and Set's (2013) claims, the dependency on internally generated capabilities can help expand or exchange across several organisation boundaries despite having a paltry amount of resources on hand. In all, the present study findings confirm the theorisations in most studies but partially support other studies (Terglav et al., 2016; Yang, 2008, 2010; Yang \& Wan, 2004) that investigate each structural path. This supports the hypothesised relationships as examined in this paper.

The empirical evidence in this study pointed idiosyncratic paths apropos to the branding activities and the expected benefits or outcomes practised by the tourist 
resorts in a developing tourism-based nation. This study has shed further insights on the widely accepted theoretical interpretations of the Resource Advantage Theory and the Knowledge Creation Theory protagonists. Based on the path analysis model results and the remaining items, our conclusions only partially support the Knowledge Creation Theory. It appears that the Resource Advantage Theory offers a better explanation in favour of our findings. The results of this study clarify that branding is paramount for enterprises from its infancy stage, and when there are only adequate resources, to invest thereafter into knowledge creation activities. The idea behind this strategy is to focus on the organisation instead of country, which developing nations suffers from poor quality image. Therefore, the tactic is to leverage on the mindset that travellers perceive the positivity to the services provided by the tourist resorts and in turn, de-emphasising the association with a developing nation that induce negative market responses (Gürhan-Canli et al., 2018; Herstein et al., 2014; Rottig \& de Oliveira, 2019).

\section{CONCLUSION AND CONTRIBUTIONS}

This study shows that organisations' ability to enhance organisational performance is dependent on how tourism entrepreneurs optimise and reconfigure their branding activities and knowledge creation process over a period of time. However, the ways in which these are combined to enhance organisational performance, at least within the branding and knowledge management literature context, are still indefinite. This study pales the need to have a high amount of physical resources on hand; unless organisations harness the organisational resources with branding activities and knowledge management, physical resources can help improve organisational performance. Furthermore, at the conceptual level, this study extends the concept of branding orientation and knowledge creation process to cover tourist resorts. Inarguably, this study on internally generated capabilities exhibited by tourism entrepreneurs provides an augmented perspective of branding and knowledge creation for tourist resorts. Therefore, tourist resorts specifically need to incorporate an integrated set of branding activities together with knowledge creation process to culminate into enhanced organisational performance.

This study makes two contributions to branding and knowledge management literature as well as the field of tourist resorts. The lacuna of theory-based studies points to scholarly avenues for empirical research, to which this study is a contribution. First, the model was tested in the provision of gaining empirical support from a sample of tourist resorts in a developing Southeast Asian nation. Liow (2017) and Set (2013) claimed that evidence from such context on the topics under review is scanty. Therefore, the findings offer some contributions 
towards comprehending and developing organisational theories applicable to the developing economies context.

Second, the obvious lack of empirical research on internally generated capabilities of tourism entrepreneurs in enhancing the organisational performance of tourist resorts solicits the call for further research, which was duly addressed in this paper. From an empirical angle, four hypotheses were tested that investigate how branding orientation as a predictor of organisational performance is mediated by knowledge creation process. Thus, this study contributes to existing studies on tourist resorts, especially as the branding and knowledge management literature mostly addresses the context of developed nations. It is anticipated that this will trigger further research in the branding and knowledge management literature on tourist resorts. Principally, the added evidence on the branding orientation and knowledge creation process of tourist resorts and the differential effects on organisational performance is timely and relevant.

\section{Theoretical and Practical Contributions}

According to the present research findings, a number of theoretical and practical contributions for tourism entrepreneurs managing tourist resorts are presented. Based on rapid real national growth and the contribution of tourist resorts to several economies, this study makes a case that branding orientation and knowledge creation as organisational strategies should receive more attention at the firm level. This study calls for attention from both scholars and the tourism entrepreneur-engagement perspective. The study also reinforces that by having the right coordination of branding orientation and knowledge creation process, organisations would be able to achieve improved organisational performance by sustaining branding activities and knowledge conversion as well as sharing with their internal and external stakeholders. Therefore, evidence was presented by means of contribution to the prevailing studies in the branding and knowledge management literature, especially as both research fields are copiously researched with studies done in developed nations. We expect the findings to trigger further investigations on managerial orientations and their distinction thereof on organisational performance is both timely and appropriate to the small and medium business entrepreneurship field. Although not exhaustive, the efforts to apply the resource-advantage theory and knowledge creation theory to examine brand orientations in tourist resorts offer a better comprehension and a few notable implications for future research.

In terms of practical contributions, several implications can be drawn. First, brandoriented tourism entrepreneurs can lead employees to develop distinctive brands to 
improve organisational performance. The identity-driven approach is of particular importance to tourist resorts in Malaysia. Committing resources to brand-building activities could help improve organisational performance. Empirically, the findings are supported by Boso et al. (2016), Casidy et al. (2018), Ciunova-Shuleska et al. (2017), and Urde et al. (2013). Second, the results suggest that it might be worthwhile for Malaysian tourism entrepreneurs to schedule knowledge gathering and knowledge sharing sessions (for example event sponsorships, press releases, sales promotions, and other events) with travel intermediaries, hotel associations, and other stakeholders. By keeping abreast with industry trends and new market knowledge, tourist entrepreneurs can implement effective branding activities to attract prospective and existing customers. Third, the results indicate that knowledge creation process has a positive and significant effect on organisational performance. To align employee branding behaviour with the desired organisational outcomes, it may be useful for tourism entrepreneurs in Malaysia to find ways to motivate their employees' involvement in knowledge creation activities. Tourism entrepreneurs can undertake the transformational leadership role to develop a vision that inspires employees to participate in knowledge creating activities (e.g., brainstorming sessions and training programmes) and use the knowledge to make informed decisions. Fourth, this study offers evidence that tourism entrepreneurs need to constantly engage with various tourism stakeholders in their corporate branding activities. In this web of relationships including employees, customers, and travel intermediaries, knowledge of the tourist resorts' products and services offered is communicated via different channels. Travel intermediaries ought to make use of online travel booking platforms to promote tourist resort packages and special deals. Meanwhile, customers would act as brand ambassadors who promote tourist resorts by word-of-mouth or sharing experiences in their social media circles. Tourism entrepreneurs instituting their own corporate websites is regarded as highly effective in attracting repetitive or new business to their resorts. On the other hand, tourism entrepreneurs can consider instructional methods that guide employees to "live the brand". This can come in the form of scripts during their point of contact with overnight guests and when executing daily work duties.

The current study results demonstrate that knowledge creation process is a partial mediator between brand orientation and organisational performance; that is, knowledge creation process influences brand orientation and enhances organisational performance to some extent. The reason could be culturally related. In Malaysia, it appears that those with the most decision-making power and authority remain first-generation leaders. Not surprisingly, the top-down approach is still widely used among these leaders. Because knowledge creation that involves government agencies, travel intermediaries, and hotel associations is mostly instituted through them, the mediating role of knowledge creation has been 
considerably less impactful. It is also worth noting that Hofstede Insights (2018) classified Malaysia as a society with a high-power distance dimension with a score 100 out of 100 , suggesting that the society accepts hierarchical order and employees are expected to follow what they are told to do. Malaysian tourism entrepreneurs tend to create brands they desire. They create and transform knowledge and confine it largely to themselves and a trusted few. Employees assume the role of service providers and executors with less involvement in knowledge creation process in the Malaysian tourism landscape.

Overall, we emphasised the importance of the tourism entrepreneurs broadening and sharpening their managerial orientations (brand orientation and knowledge creation process) to overcome the industry knowledge gaps to outperform their competitors in terms of organisational performance since implementation of such efforts is highly dependent on the tourism entrepreneur themselves.

\section{Limitations and Future Research Directions}

Two recommendations for future research are put forward. First, this study considered one-star to five-star tourist resorts in 13 states in Malaysia. Future research may consider other travel and tourism-related businesses, such as food service and travel agencies, or broaden the coverage to include budget hotels, city hotels, and town hotels. Second, this study examined the interrelationships between brand orientation, knowledge creation process, and organisational performance. Future research could consider other variables, such as entrepreneurial orientation, and social and environmental influences as well as the potential of government policies to have an impact on organisational performance.

\section{REFERENCES}

Aaker, D.A. (1991). Managing brand equity. New York: The Free Press.

Acs, Z.J., Brooksbank, D.J., O'Gorman, C., Pickernell, D., \& Terjesen, S. (2012). The knowledge spillover theory of entrepreneurship: An application to foreign direct investment. International Journal Entrepreneurship and Small Business, 15(2), 237-261. https://doi.org/10.1504/ijesb.2012.045206

Al-Nuiami, M., Idris, W.M.S., Al-Ferokh, F.A.M., \& Abu Joma, M.H.M. (2014). An empirical study of the moderator effect of entrepreneurial orientation on the relationship between environmental turbulence and innovation performance in five-star hotels in Jordan. International Journal of Business Administration, 5(2): 111-125. https://doi.org/10.5430/ijba.v5n2p111

Awang, Z. (2015). SEM made simple. Bandar Baru Bangi, Selangor: MPWS Rich Publication Sdn. Bhd. 
Ayob, F., Wilson-Evered, E., \& McGrath, M. (2017). An empirical study of the web presence model to evaluate the web features of small-and-medium-sized hotels (SMHs) in the Malaysia hotel industry. In CAUTHE 2017, Time for Big Ideas? Rethinking the Field for Tomorrow, 7 February-10 April 2017, Dunedin, New Zealand. Retrieved 1 July 2018 from http://vuir.vu.edu.au/id/eprint/33095

Bentler, P.M. (1990). Comparative fit indexes in structural models. Psychological Bulletin, 107(2), 238-246. https://doi.org/10.1037//0033-2909.107.2.238

Boso, N., Carter, P.S., \& Annan, J. (2016). When is brand orientation a useful strategic posture? Journal of Brand Management, 23(4), 363-382. https://doi.org/10.1057/ bm.2016.15

Bollen, K.A. (1989). A new incremental fit index for general structural equation models. Sociological Methods and Research, 17(3), 303-316. https://doi. org/10.1177/0049124189017003004

Byrne, B.M. (2010). Structural equation modelling with AMOS: Basic concepts, applications, and programming (2nd ed.). New York: Routledge.

Casidy, R., Wymer, W., \& O'Cass, A. (2018). Enhancing hotel brand performance through fostering brand relationship orientation in the minds of consumers. Tourism Management, 66(June), 72-84. https://doi.org/10.1016/j.tourman.2017.11.008

Chen, F-H., Hsu, T-S., \& Tzeng, G-H. (2011). A balanced scorecard approach to establish a performance evaluation and relationship model for hot spring hotels based on a hybrid MCDM model combining DEMATEL and ANP. International Journal of Hospitality Management, 30(4): 908- 932. https://doi.org/10.1016/j. ijhm.2011.02.001

Chokesikarin, V. (2014). Entrepreneurial orientation and customers satisfaction: Evidences nearby Khao San Road. International Journal of Social, Management, Economics and Business Engineering, 8(1), 71-76.

Ciunova-Shuleska, A., Palamidovska-Sterjadovska, N., Osakwe, C.N., \& Omotoso, J. (2017). The impact of customer retention orientation and brand orientation on customer loyalty and financial performance in SMEs: Empirical evidence from a Balkan country. Journal of East European Management Studies, 22(1), 83-104. https://doi.org/10.5771/0949-6181-2017-1-83

Cohen, J. (1988). Statistical power analysis for the behavioural science. Hillsdale, New Jersey: Lawrence Erlbaum.

De Chernatony, L., \& Riley, F.D.O. (1998). Modelling the components of the brand. European Journal of Marketing, 32(11/12), 1074-1090. https://doi. org/10.1108/03090569810243721

Department of Statistics, Malaysia. (2018, January 29). Economic census 2016: Tourism statistics. Retrieved 4 November 2018 from https://www.dosm.gov.my/v1/ index.php?r=column/ctheme\&menu_id=b0pIV1E3RW40VWRTUkZoc EhyZ1pLUT09\&bul_id=VmZsbTU4NDIFcFZRdVF6ZDF3OW4zZz09\#

Ewing, M.T., \& Napoli, J. (2005). Developing and validating a multidimensional nonprofit brand orientation scale. Journal of Business Research, 58(6), 841-853. https://doi.org/10.1016/j.jbusres.2003.09.012 
Giampaoli, D., Ciambotti, M., \& Bontis, N. (2017). Knowledge management, problem solving and performance in top Italian firms. Journal of Knowledge Management, 21(2), 355-375. https://doi.org/10.1108/jkm-03-2016-0113

Gold, A.H., Maholtra, A., \& Segars, A.H. (2001). Knowledge management: An organizational capabilities perspective. Journal of Knowledge Management Information Systems, 18(1), 185-214. https://doi.org/10.1080/07421222.2001.1 1045669

Green, J.P., Tonidaandel, S., \& Cortina, J.M. (2016). Getting through the gate: Statistical and methodological issues raised in the reviewing process. Organizational Research Methods, 19(3), 402-432. https://doi.org/10.1177/1094428116631417

Gürhan-Canli, Z., Sarial-Abi, G., \& Hayran, C. (2018). Consumers and brands across the globe: Research synthesis and new directions. Journal of International Marketing, 26(1), 96-117. https://doi.org/10.1509/jim.17.0063

Haber, S., \& Reichel, A. (2005). Identifying performance measures of small ventures: The case of the tourism industry. Journal of Small Business Management, 43(3), 257-286. https://doi.org/10.1111/j.1540-627x.2005.00137.x

Hair, J.F., Black, W.C., Babin, B.J., \& Anderson, R.E. (2010). Multivariate data analysis: A global perspective (7th ed.). New Jersey: Pearson.

Hariandja, E.S. (2011). The relationship between service innovation, marketing communication, and performance in hospitality industries: A conceptual framework. Proceeding of Industrial Engineering and Service Science, 20-21.

Herstein, R., Berger, R., \& Jaffe, E.D. (2014). How companies from developing and emerging countries can leverage their brand equity in terms of place branding. Competitiveness Review, 24(4), 293-305. https://doi.org/10.1108/cr-04-20130046

Hofstede Insights. (2018). What about Malaysia? Retrieved 4 November 2018 from https:// www.hofstede-insights.com/country-comparison/malaysia/

Holmes-Smith, P., Coote, L., \& Cunningham, E. (2006). Structural equation modelling: From the fundamental to advanced topics. Malvern East, Victoria, Australia: School of Research Evaluation and Measurement Services (SREAMS).

Hunt, S.D. (1995). The resource-advantage theory of competition: Toward explaining productivity and economic growth. Journal of Management Inquiry, 4(4), 317332. https://doi.org/10.1177/105649269500400403

Hunt, S.D., \& Arnett, D.B. (2006). Does marketing success lead to market success? Journal of Business Research, 59(7), 820-828. https://doi.org/10.1016/j. jbusres.2006.01.019

Hunt, S.D., \& Morgan, R.M. (1995). The comparative advantage theory of competition. The Journal of Marketing, 59(1), 1-15.

Ismail, T.A.T., Muhammad, R., Yusoff, N.M., \& Shariff, M.S.M. (2016). The myth and reality of hotel brand and food quality: The case of hotel restaurants in Malaysia. Procedia-Social and Behavioral Sciences, 222, 382-389. https://doi. org/10.1016/j.sbspro.2016.05.187

Keller, K.L. (2000). The brand report card. Harvard Business Review, 78(1), 147-156. 
Kim, S., Im, H.H., \& King, B. (2015). Muslim travellers in Asia: The destination preferences and brand perceptions of Malaysian tourists. Journal of Vacation Marketing, 21(1), 3-21. https://doi.org/10.1177/1356766714549648

Lahap, J., Ramli, N.S., Said, N.M., Radzi, S.M., \& Zain, R.A. (2016). A study of brand image towards customer's satisfaction in the Malaysian hotel industry. Procedia -Social and Behavioral Sciences, 224(June), 149-157. https://doi.org/10.1016/j. sbspro.2016.05.430

Laukkanen, T., Tuominen, S., Reijonen, H., \& Hirvonen, S. (2016). Does market orientation pay off without brand orientation? A study of small business entrepreneurs. Journal of Marketing Management, 32(7-8), 673-694. https://doi.org/10.1080/ 0267257x.2015.1122659

Lee, H., \& Choi, B. (2003). Knowledge management enablers, processes, and organizational performance: An integrative view and empirical examination. Journal of Management Information Systems, 20(1), 179-228. https://doi.org/10.1080/074 21222.2003.11045756

Li, Y.H., Huang, J.W., \& Tsai, M.T. (2009). Entrepreneurial orientation and firm performance: The role of knowledge creation process. Industrial Marketing Management, 38(4), 440-449. https://doi.org/10.1016/j.indmarman.2008.02.004

Liow, L.S.M. (2017). The mediating effect of knowledge creation process on branding, entrepreneurship and customers' orientations towards the performance of small and medium tourism accommodation businesses in Malaysia. PhD dissertation, International University of Malaya-Wales, Kuala Lumpur, Malaysia.

Liow, M.L.S., \& Yeow, K.C. (2015). Performance measurable in the accommodation industry: A dilemma and beyond. The International Journal of Business \& Management, 3(3), 99.

Manthiou, A., Kang, J., Sumarjan, N., \& Tang, L. (2016). The incorporation of consumer experience into the branding process: An investigation of name-brand hotels. International Journal of Tourism Research, 18(2), 105-115. https://doi. org/10.1002/jtr.2037

Muhonen, T., Hirvonen, S., \& Laukkanen, T. (2017). SME brand identity: Its components, and performance effects. Journal of Product \& Brand Management, 26(1), 52-67. https://doi.org/10.1108/jpbm-01-2016-1083

Mulyanegara, R.R.C. (2010). Market orientation \& brand orientation from customer perspective: An empirical examination in the non-profit sector. International Journal of Business and Management, 5(7), 14-19. https://doi.org/10.5539/ijbm. $\mathrm{v} 5 \mathrm{n} 7 \mathrm{p} 14$

Nonaka, I. (1994). A dynamic theory of organizational knowledge creation. Organizational Science, 5(1), 14-37.

Nonaka, I., \& Konno, N. (1998). The concept of "ba": Building a foundation for knowledge creation. California Management Review, 40(3), 40-54. https://doi. org/10.2307/41165942

Nonaka, I., \& Takeuchi, H. (1995). The knowledge-creating company: How Japanese companies create the dynamics of innovation. New York: Oxford University Press. 
Nonaka, I., \& Toyama, R. (2005). The theory of the knowledge-creating firm: Subjectivity, objectivity and synthesis. Industrial and Corporate Change, 14(3), 419-436. https://doi.org/10.1093/icc/dth058

Peters, M., Pfurtscheller, A., Wong, K.K.F., \& Kraus, S. (2010). The influence of entrepreneurial branding on entrepreneurial/growth orientations: An empirical study in the Austrian tourism industry. International Journal of Business Research, 10(2), 28-29.

Porter, M.E. (1985). Competitive advantage. New York: Free Press.

Rottig, D., \& de Oliveira, R.T. (2019). International expansion of Chinese emerging market multinational corporations to developed markets: A qualitative analysis of postacquisition and integration strategies. In A. Vecchi (Ed.), Chinese acquisitions in developed countries (pp. 37-53). Cham, Switzerland: Springer. https://doi. org/10.1007/978-3-030-04251-6_3

Sabherwal, R., \& Becerra-Fernandez, I. (2003). An empirical study of the effect of knowledge management processes at individual, group, and organisational levels. Decision Sciences, 34(2), 225-260. https://doi.org/10.1111/1540-5915.02329

Saunders, M., Lewis, P., \& Thornhill, A. (2012). Research methods for business student (6th ed.). Essex: Pearson Education Limited.

Set, K. (2013). Tourism small and medium enterprises (TSMEs) in Malaysia. International Journal of Business and Social Science, 4(16), 58-66.

Sigala, M., \& Chalkiti, K. (2007). Improving performance through tacit knowledge externalisation and utilization: Preliminary findings from Greek hotels. International Journal of Productivity and Performance Management, 56(5/6), 456-483. https://doi.org/10.1108/17410400710757141

Tajeddini, K. (2010). Effect of customer orientation and entrepreneurial orientation on innovativeness: Evidence from the hotel industry in Switzerland. Tourism Management, 31(2), 221-231. https://doi.org/10.1016/j.tourman.2009.02.013

Tang, C.F., \& Tan, E.C. (2015) Does tourism effectively stimulate Malaysia's economic growth? Tourism Management, 46, 148-163. https://doi.org/10.1016/j. tourman.2014.06.020

Terglav, K., Ruzzier, M.J., \& Kase, R. (2016). Internal branding process: Exploring the role of mediators in top management's leadership-commitment relationship. International Journal of Hospitality Management, 54, 1-11. https://doi. org/10.1016/j.ijhm.2015.12.007

Thomas, R., Shaw, G., \& Page, S.J. (2011). Understanding small firms in tourism: A perspective on research trends and challenges. Tourism Management, 32(5), 963976. https://doi.org/10.1016/j.tourman.2011.02.003

Tsiotsou, R., \& Ratten, V. (2010). Future research directions in tourism marketing. Marketing Intelligence \& Planning, 28(4), 533-544. https://doi. org/10.1108/02634501011053702

Urde, M., Baumgarth, C., \& Merrilees, B. (2013). Brand orientation and market orientation: From alternatives to synergy. Journal of Business Research, 66(1), 13-20. https:// doi.org/10.1016/j.jbusres.2011.07.018 
Wilkins, H. (2010). Using importance-performance analysis to appreciate satisfaction in hotels. Journal of Hospitality Marketing \& Management, 19(8), 866-888. https:// doi.org/10.1080/19368623.2010.514554

Xin, J.Y., Ramayah, T., Soto-Acosta, P., Popa, S., \& Teoh, A.P. (2014). Analyzing the use of Web 2.0 for brand awareness and competitive advantage: An empirical study in the Malaysian hospitality industry. Information Systems Management, 31(2), 96-103. https://doi.org/10.1080/10580530.2014.890425

Yang, J-T. (2008). Individual attitudes and organisational knowledge sharing. Tourism Management, 29(2), 345-353. https://doi.org/10.1016/j.tourman.2007.03.001

Yang, J-T. (2010). Antecedents and consequences of knowledge sharing in international tourist hotels. International Journal of Hospitality Management, 29(1), 42-52. https://doi.org/10.1016/j.ijhm.2009.05.004

Yang, J-T., \& Wan, C-S. (2004). Advancing organisational effectiveness and knowledge management implementation. Tourism Management, 25(5), 593-601. https://doi. org/10.1016/j.tourman.2003.08.002

Zeglat, D., \& Zigan, K. (2014). Intellectual capital and its impact on business performance: Evidences from the Jordanian hotel industry. Tourism and Hospitality Research, 13(2), 83-100. https://doi.org/10.1177/1467358413519468 